ARTICLE HISTORY: Received: January 18, 2021 Accepted: March 13, 2021 Published: March 19, 2021

ВОССТАНОВЛЕНИЕ ПРАВА КОРПОРАТИВНОГО КОНТРОЛЯ

\author{
Пелехова Екатерина Михайловна, \\ магистрант \\ Ярославский государственный университет \\ им. П.Г. Демидова
}

\title{
RESTORATION OF THE RIGHT OF CORPORATE CONTROL
}

\author{
Pelekhova Ekaterina Mikhailovna, \\ magistrant \\ Yaroslavl State University \\ named after P.G. Demidov
}

\begin{abstract}
Аннотация. В статье рассматривается фактически новый способ защиты гражданских прав в сфере корпоративного права, связанный с возвратом доли участия в уставном капитале хозяйственного общества. Отсутствие своевременного обращения внимания к заданной проблематике со стороны российской доктрины, вынудило судебную практику сформулировать концепцию восстановления права корпоративного контроля. Исследована специфика и условия применения данного способа защиты.

Abstract. The article deals with a virtually new way of protecting civil rights in the field of corporate law, associated with the return of a share in the authorized capital of a business company. The lack of timely attention to this issue on the part of the Russian doctrine forced the court practice to formulate the concept of restoring the right of corporate control. Its specificity and the conditions for the use of this method of protection are investigated.

Ключевые слова: способы защиты прав, корпоративный контроль, требование о восстановлении корпоративного контроля.
\end{abstract}

Keywords: ways to protect rights, corporate control, the requirement to restore corporate control.

Защита прав участника общества, при утрате им корпоративного контроля сопровождалась определенными трудностями, иногда уничтожающими возможность возврата доли, при использовании существовавших способов защиты гражданских прав. Такое положение дел приводило к незащищенности участников общества, ввиду возможности безнаказанного хищения их доли участия в юридическом лице: акции, доли в уставном капитале.

Корпоративные правоотношения включают в себя способы защиты корпоративных прав, которые имеют дуалистическую правовую природу: первая часть корпоративных прав - вещная, вторая - обязательственная. Участники корпораций применяют как традиционные способы защиты корпоративных прав, к которым можно отнести: признание права собственности на акции и доли в уставном капитале корпораций, признание сделок недействительными и применение последствий её недействительности, так и специальные способы, например, признание недействительным решения собрания, в случае нарушения права лица на управление, а именно не извещение акционера о проведении общего собрания, из-за чего он не принял в нем участия, хотя на сегодняшний день данный способ, думаем, следует отнести также к традиционным. В свою очередь, восстановить корпоративный контроль традиционными способами, представляется, не вполне возможным. Это связано с тем, что утрата доли участия в юридическом лице влечет также потерю прав, вытекающих из неё, что, создает угрозу нарушения комплекса удостоверенных долей корпоративных прав. Иными словами, лицо, из-за неправомерных действий которого, потерпевший утрачивает долю участия в юридическом лице, получает возможность осуществлять все предусмотренные этой долей права. Очевидно, что в большинстве случаев потерпевший стремится наиболее полно восстановить права, в связи с чем, прибегает к способам защиты, направленных на возврат доли.

Поэтому весомую часть дел из общего массива споров о восстановлении прав участников корпораций, рассматриваемых арбитражными судами, занимают споры о восстановлении корпоративного контроля. Тем не менее, до сих пор в российском законодательстве не закреплено такое понятие как «корпоративный контроль» $[1$, с. 66]. Несмотря на это, судьи активно используют этот термин при вынесении решений. Впервые рассматриваемый термин появился в Постановлении Президиума Высшего Арбитражного Суда РФ (далее Президиум ВАС РФ) от 3 июня 2008 г. № 1176/08 по делу № A14-14857/2004-571/21 [2]. В рассматриваемом деле оспаривалось заключение неуполномоченным лицом сделки с долей в уставном капитале общества с ограниченной ответственностью и возврата этой доли истцу. Президиум ВАС РФ вышел за рамки просительной части заявления истца, указав, что требования истца носят не реституционный характер, а направлены на 
восстановление корпоративного контроля в целом. В противном случае истец был бы вправе получить от ответчика лишь компенсацию в размере стоимости доли по заниженной цене в результате проведенной оценки, а также невозможность исполнения судебного решения.

Далее требования о восстановлении корпоративного контроля встречается в Постановлении Президиума ВАС РФ в деле № А40-11837/06-138-91[3]. Здесь истец заявил требование о признании права на долю в уставном капитале общества с ограниченной ответственностью, которая была отчуждена третьему лицу несмотря на то, что спор об исключении истца из общества ещё находился на рассмотрении суда. В рассматриваемых делах, можно заметить, что требования различны по своей природе, так, в первом случае требование о реституции, во втором - о признании права. Вместе с тем, Президиум ВАС РФ посчитал, что в обоих делах суть требований заключается в восстановлении права на корпоративный контроль. В дальнейшем, формулировка «восстановления корпоративного контроля» стала широко использоваться в российской арбитражной практике, то есть присуждения стороне спора доли в уставном капитале общества, не связанного с изъятием этой доли у другого лица.

Федеральным законом от 5 мая 2014 г. № 99-ФЗ восстановление корпоративного контроля как новая форма защиты участников корпорации была законодательно закреплена в п. 3 ст. 65.2 Гражданского Кодекса Российской Федерации [4, ст. 65.2] (далее - ГК РФ), что, по нашему мнению, следует рассматривать как безусловное достижение российского законодателя. Дополненная гл. 4 ГК РФ ст. 65.2. в п. 3 стала определять порядок восстановления прав при утрате доли участия в юридическом лице. Так, участник коммерческой корпорации, утративший помимо своей воли в результате неправомерных действий других участников или третьих лиц права участия в ней, вправе требовать возвращения ему доли участия, перешедшей к иным лицам, с выплатой им справедливой компенсации, определяемой судом, а лица, виновные в утрате доли, обязаны в свою очередь возместить причиненные убытки.

Как можно заметить, вышеназванная норма не только стала обозначать восстановление корпоративного контроля на законодательном уровне, но и внесла некоторые уточнения. Во-первых, пояснено, что данный способ защиты применяется только в отношении участников коммерческих корпораций, учитывая интересы добросовестных приобретателей корпоративных прав, которые первоначально были неправомерно отчуждены другими участниками или третьими лицами. В зависимости от ситуации приобретатели могут претендовать на справедливую компенсацию утраченной ими доли участия в корпорации, размер которой определяется судом и, следовательно, не подлежит доказыванию истцом. Во-вторых, приведены случаи, когда в удовлетворении требования истца может быть отказано (если приводит к несправедливому лишению иных лиц их прав участия или повлечет крайне негативные социальные и другие публично значимые последствия) [5, с. 63].

В результате анализа судебной практики по спорам о восстановлении корпоративного контроля можно выделить ряд условий, при наличии которых в обязательном порядке удовлетворяются заявленные истцом требования:

1. Истец должен доказать, что его права были нарушены, то есть доля участия в юридическом лице была утрачена в результате незаконных действий третьих лиц. Добросовестность по смыслу п. 3 ст. 65.2 ГК РФ влияет на размер компенсации добросовестному приобретателю, а не на удовлетворения иска в целом. При этом обязанность выплачивать компенсацию возлагается на истца, незаконно лишенного доли в уставном капитале общества. Это означает, что закон допускает ситуацию, когда незаконно лишенный участник доли в уставном капитале общества остается и без доли, и без справедливой компенсации, поскольку у лиц, виновных в утрате доли, может отсутствовать имущество для справедливой компенсации [6, с. 10].

3. Недобросовестность ответчика. С.В. Сарбаш полагает, что в основе этого условия лежит компромисс между защитой субъективных прав, принадлежащих одному лицу, стабильностью гражданского оборота и прав приобретателей имущества [7, с. 77].

3. Данный способ защиты нарушенных прав применяется к определенной группе споров, когда невозможно полное восстановление права путем использования иных способов защиты, чем подчеркивается его исключительность.

4. Утрата корпоративного контроля, а не просто доли участия в уставном капитале корпорации произвольного размера. Указанное условие является обязательным, так как право корпоративного контроля принадлежит участнику, владеющему определенным количеством акций или долей в уставном капитале хозяйственного общества. Размер доли участия определяется индивидуально применительно к каждому спору, в том числе с учетом положений учредительных документов юридического лица.

Стоит заметить, что концепция «восстановление корпоративного контроля», прочно вошедшая в научную доктрину и практику до сих пор отсутствует в ГК РФ, что, по нашему мнению, является пробелом в законодательстве. В связи с этим предлагаем дополнить ст. 12 ГК РФ таким способом защиты, как «восстановление корпоративного контроля», что позволит решить ряд задач, а именно, появиться возможность отграничить данный способ от смежных, подчеркивая и придавая корпоративную идентичность, также введение термина как нормативной дефиниции будет способствовать гармонизации российского корпоративного 
законодательства, приведению его в соответствие с общепризнанными международными стандартами в этой сфере и повышению инвестиционной привлекательности российской правовой системы в целом.

\section{Список использованных источников}

1. Смирнова Е.И. Восстановление корпоративного контроля как способ защиты прав участников корпораций // Юридические науки. 2017. № 4 (31). С. 66-67.

2. Постановление Президиума ВАС РФ от 3 июня 2008 г. № 1176/08 по делу № А14-14857/2004-571/21 // Вестник ВАС РФ. 2008. № 10.

3. Постановление Президиума ВАС РФ от 10 июня 2008 г. № 5539/08 по делу № A40-11837/06-138-91// Вестник ВАС РФ. 2008. № 10.

4. Гражданский кодекс Российской Федерации от 30 ноября 1994 г. № 51-ФЗ. Часть 1 // Собрание законодательства РФ. 1994. № 32, ст. 3301 (с изм. и доп.).

5. Белин Е.А. Восстановление корпоративного контроля как специфический способ защиты гражданских прав. Его правовая природа // Молодая наука в классическом университете: тезисы докладов научных конференций фестиваля студентов, аспирантов и молодых ученых. Иваново, 2016. 140 с.

6. Белоножко Е.Е. Гражданско-правовые способы защиты права от рейдерских захватов доли участия в уставном капитале общества с ограниченной ответственностью: правовые проблемы реализации // Наука. Общество. Образование». 2017. № 2. С. 8-12.

7. Сарбаш С.В. Восстановление корпоративного контроля // Вестник гражданского права. 2008. № 4. C. 76-79.

\section{References}

1. Smirnova E.I. Restoration of corporate control as a way to protect the rights of corporate participants / / YUridicheskie nauki. 2017. No. 4 (31). pp. 66-67. (In Russian).

2. Postanovlenie Prezidiuma VAS RF ot 3 iyunya 2008 g. № 1176/08 po delu № A14-14857/2004-571/21 // Vestnik VAS RF. 2008. № 10.

3. Postanovlenie Prezidiuma VAS RF ot 10 iyunya 2008 g. № 5539/08 po delu № A40-11837/06-138-91 // Vestnik VAS RF. 2008. № 10.

4. Grazhdanskij kodeks Rossijskoj Federacii ot 30 noyabrya 1994 g. № 51-FZ. CHast' 1 // Sobranie zakonodatel'stva RF. 1994. № 32, st. 3301 (s izm. i dop.).

5. Belin E.A. Restoration of corporate control as a specific way to protect civil rights. Its legal nature // Molodaya nauka v klassicheskom universitete: tezisy dokladov nauchnyh konferencij festivalya studentov, aspirantov i molodyh uchenyh. Ivanovo, 2016. 140 p. (In Russian).

6. Belonozhko E.E. Civil-legal ways to protect the right from raider seizures of the share of participation in the authorized capital of a limited liability company: legal problems of implementation. // Nauka. Obshchestvo. Obrazovanie. 2017. No. 2. pp. 8-12. (In Russian).

Sarbash S.V. Restoring corporate control // Vestnik grazhdanskogo prava. 2008. No. 4. pp. 76-79. (In Russian). 